\title{
Erratum to: In Memorian Thomas W. Hesterberg, PhD MBA (1950-2016)
}

David B. Warheit

\section{Erratum}

After the publication of this work [1] it was noticed that the title of the article was incorrect. The correct title should read: Tom Hesterberg-In Memoriam.

Received: 21 April 2017 Accepted: 21 April 2017

Published online: 27 April 2017

\section{Reference}

1. Warheit DB. In Memorian Thomas W. Hesterberg, PhD MBA (1950-2016).

Part Fibre Toxicol. 2017;14:9. 